\title{
Effect of Internet Banking on Operational Performance of Commercial Banks in Nakuru County, Kenya
}

\author{
Hussein Mohamed Abdullai ${ }^{1}$, Elyjoy Muthoni Micheni ${ }^{2}$ \\ ${ }^{1}$ Department of Accounting, Finance and Management Science, Egerton University, Nakuru, Kenya \\ ${ }^{2}$ Department of Management Science and Technology, The Technical University of Kenya, Nairobi, Kenya \\ Email address: \\ hussumoha@yahoo.com(H. M. Abdullai),elyjoymicheni@gmail.com (E.M. Micheni)
}

\section{To cite this article:}

Hussein Mohamed Abdullai, Elyjoy Muthoni Micheni. Effect of Internet Banking on Operational Performance of Commercial Banks in Nakuru County, Kenya. International Journal of Economics, Finance and Management Sciences. Vol. 6, No. 2, 2018, pp. 60-65. doi: $10.11648 /$ j.ijefm.20180602.14

Received: January 10, 2018; Accepted: March 27, 2018; Published: May 5, 2018

\begin{abstract}
The purpose of this paper was to investigate the effect of internet banking on operational performance of commercial banks in Nakuru County, Kenya. The study was guided by the research objective: to investigate the effect of internet banking on operational performance of commercial banks in Nakuru County. The study employed the following theories namely: Bank-Focused Theory and The Technology Acceptance Model (TAM). This study adopted a cross-sectional research design. A cross-sectional research design is a research approach in which the researchers investigate the state of affairs in a population at a certain point in time. Very often, the elements in the sample survey are selected at random to make inference about the population as a whole [21]. The study population comprised of 56 employees of the commercial banks. Since the banks are few, the study adopted a census survey. Data was collected using structured questionnaires. A pilot study was conducted in Uasin Gishu County to determine validity of the research instruments where Cronbach's alpha coefficient (0.7) was employed. Data was analyzed using correlation and regression analysis. The study established that internet banking has a positive significant effect on operational performance of the commercial banks. The study recommends that managements of commercial banks should invest in internet banking as it positively influences operational performance. The study suggests that further studies should be conducted to establish the effect of internet banking on operational performance in other sectors other than banking as the study focused only on commercial banks in order to establish whether internet banking does affect their operational performance.
\end{abstract}

Keywords: Internet Banking, Operational Performance, Commercial Banks

\section{Introduction}

Innovation is considered to be a critical requirement for the growth and profitability of organizations. One of the ways to achieving growth and sustaining performance is to encourage and foster innovative practices and creativity internally within the institution. For banking organizations operating in increasingly competitive market, innovation is often a condition for simple survival. The capability to innovate is ever more viewed as the single most vital factor in developing and supporting competitive advantage [14]. To remain competitive, firms need to be flexible to be able to respond rapidly to the fast changing market environment to which they are exposed. Actually, banking environment worldwide has become transformed over the years and the banking public has become more sophisticated in their purchase decisions. To respond to increasingly sophisticated customer and market demand therefore, banks need to put in place operational processes that ensure greater customer convenience, better delivery of and increased accessibility to financial services and products [18]. The adoption of electronic banking by deposit money banks have offered increased services to customers with attendant increase in customer risk exposure. The effectiveness of deploying Information Technology in banks therefore cannot be put to doubt. The fact remains that the reality of using IT in banks is necessitated by the huge amount of information being handled by these banks on a daily basis. On the customers' side, cash is withdrawn or deposited, cheques are deposited or cleared, statement of accounts are provided, money 
transfers etc. At the same time, banks need up-to-date information on accounts, credit facilities and recovery, interest, deposits, charges, income, profitability indices and other control of financial information. However, researchers have not given much attention to this revolution occasioned by electronic banking with regard to operational performance of banks [4].

There are many different ways of measuring operational performance. However, the most predominant approach in the literature is to use cost, quality, delivery, speed, reliability and flexibility as the basic dimensions of operational performance [3].

\subsection{Statement of the Problem}

Industry analysis outlining the potential impact of electronic banking on cost savings, revenue growth and risk profile of the banks have generated considerable interest and speculation about the impact of the information technology on the banking industry [17]. Internet banking in Kenya has emerged as a strategic resource for achieving higher efficiency, control of operations and reduction of cost by replacing paper based and labour intensive methods with automated processes thus leading to higher productivity and profitability. However, to date researchers have produced little evidence regarding these potential changes. Nonetheless, recent empirical studies indicate that electronic banking is not having an independent effect on banking profitability, although these findings may change as the use of the Internet becomes more widespread [13]. None of these studies focused on the effect of internet banking on operational performance of commercial banks. Hence, this study sought to fill the existing research gap by investigating the effect of internet banking on operational performance of commercial banks in Nakuru County, Kenya.

\subsection{Objective of the Study}

To investigate the effect of Internet banking on operational performance of commercial banks in Nakuru County, Kenya.

\subsection{Research Hypothesis}

$\mathrm{H}_{01}$ : There is no significant relationship between Internet banking and operational performance of commercial banks in Nakuru County, Kenya.

\subsection{Conceptual Framework}

In this framework, internet banking is independent variable and operational performance is dependent variable. The independent variable internet banking is operationalized through; checking account balance, paying bills and fund transfer while the dependent variable is operationalized through: cost of operations, reliability of service and speed of service delivery. The intervening variable is concerned with management and staff level of ICT literacy, staff willingness to adopt automation and rules and regulations of Central Bank of Kenya governing the commercial bank

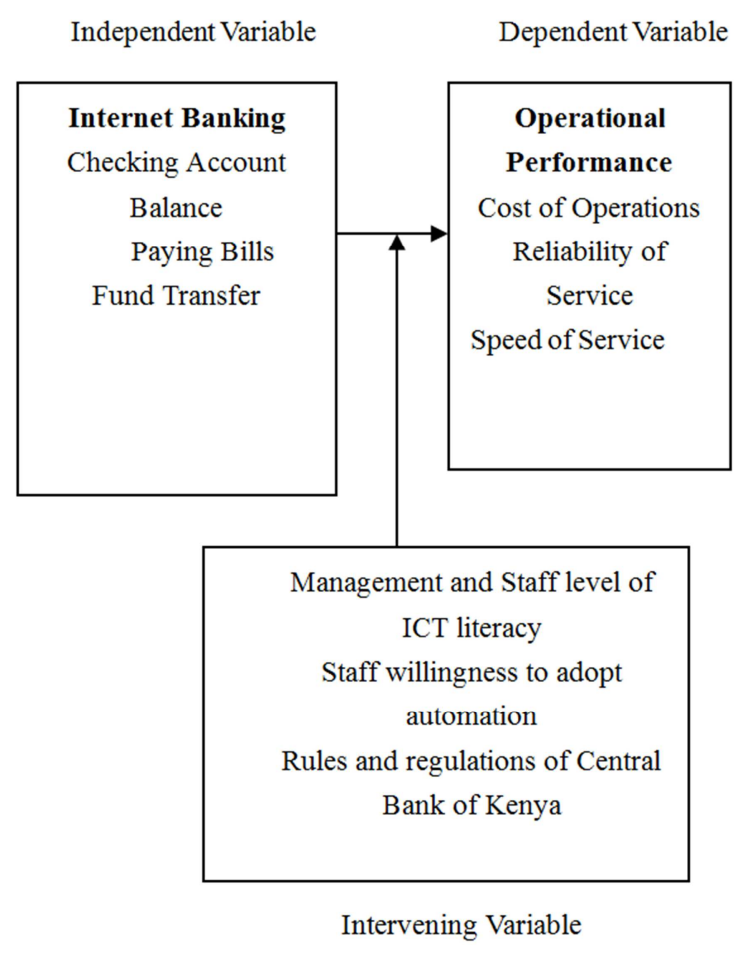

Figure 1. Conceptual Framework.

\section{Literature Review}

\subsection{Bank-Focused Theory}

Bank focused theory emerges when a traditional bank uses non-traditional low-cost delivery channels to provide banking services to its existing customers. Examples range from use of automated teller machine (ATMs) to Internet banking or mobile phone banking to provide certain limited banking services to banks' customers. In the context of this study, this theory proposes that commercial banks switch from their old method of service delivery commonly referred to as traditional methods to new methods of service delivery commonly known as non-traditional methods [13].

\subsection{Theory of Reasoned Action}

This theory was developed by Davis in 1985. Technology Acceptance Model (TAM) theorizes that an individual's behavioral intention to adopt a particular piece of technology is determined by the individual's attitude toward the use of that technology. Attitude, in turn, is induced by two beliefs: perceived usefulness and perceived ease of use. Perceived usefulness is defined as the extent to which persons believe that technology will enhance their productivity or job performance [5]. TAM research has shown that perceived usefulness is a strong determinant of user acceptance, adoption, and usage behavior and perceived ease of use is defined as the degree to which an individual believes that using a technology will be simple. In the context of this study, the theory proposes that the customers', bankers' and management's behavioral intention determines the attitude toward adoption of the technology. 


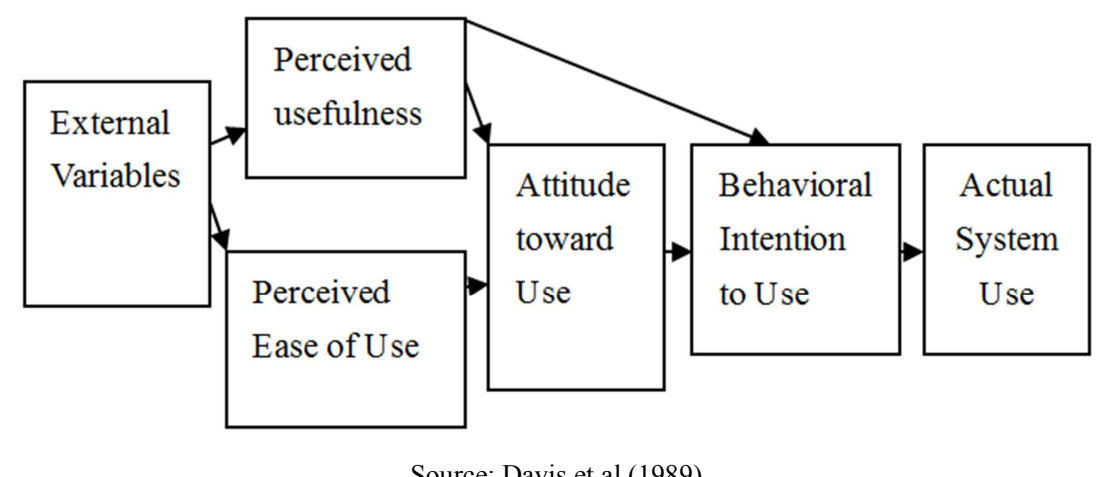

Source: Davis et al (1989)

Figure 2. Technology Acceptance Model.

\subsection{Empirical Review}

\subsubsection{Internet Banking}

Internet banking is defined as an Internet portal, through which consumers can use different kind of banking services ranging from bill payment to making investment, thus banks just offering information through their websites are not considered as using Internet banking [16]. Evidence from survey studies and from banks' websites indicated that banks in North Cyprus have been consistently moving towards providing Internet banking services despite a very small potential market to share [9]. In 2004, the majority of commercial banks claim that the potential market is too small to adopt Internet banking services in North Cyprus. Yet, in 2006 the same banks are in the process of introducing Internet banking as an assurance to their customers that they would be able to maintain a competitive quality of service in the future, hence avoiding losing their customers, to the branches of foreign.

E-banking has strong and significant marginal effects on return on assets in the Kenyan banking sector and the electronic banking has made banking transaction to be easier by bringing services closer to customers hence improving banking industry performance [2]. There is a strong positive relationship between financial performance of commercial banks and Internet banking. Internet banking also helps the commercial banks to lower their cost of banking, through technology which has created greater opportunities to the banks to offer great flexibility to the customers [12]. Commercial banks are also interested in expanding their market through Internet banking. E-banking has enhanced the growth of customer base for the banking institutions in Kenya, through enhancing banking services accessibility to a larger population in the country and the study recommends that banks should embrace e-banking as a key competitive advantage [20]. Internet banking renders location and time irrelevant, and empowers customers with greater control of their accounts [6]. Banks achieve cost and efficiency gains in a large number of operational areas. Adoption of Internet banking has enhanced performance of the banking industry [15].

Internet banking allows customers to perform a wide range of banking transactions electronically via the bank's
Web site. When first introduced, Internet banking was used mainly as an informational medium in which banks marketed their products and services on their Websites. With the development of secured transaction technologies, more banks are using Internet banking as a transactional as well as an informational medium. As a result Internet banking users can now perform common banking transactions such as writing checks, paying bills, transferring funds, printing statements and checking account balances online using a computer [10].

\subsubsection{Internet Banking and Operational Performance}

Operational performance is a process of assessing progress toward achieving predetermined goals, including information on the efficiency with which resources are transformed into outputs both goods and services [7] whose quality depend on delivery and satisfaction to clients [12].

Operational performance of service delivery comprises three critical performance factors (quality, dependability, and speed) that are usually present in a service delivery system. Consistent quality, dependability of delivery, and prompt delivery (speed) are critical operations performance factors in service delivery systems [11] and reflects more directly to the efficiency and effectiveness of the operations within the firm [7]. These categories of performance reflect competencies in specific areas of supply chain including cost, quality, and flexibility. There are four criteria to measure the operational performance; are quick delivery compared to the major competitor, unit cost of productrelative to competitors, overall productivity and overall customer satisfaction. They are derived from several criteria, which have been conceptualized and used in previous empirical studies of lean manufacturing and supply chain management [17].

\section{Research Methodology}

\subsection{Research Design}

This study adopted a cross-sectional research design. A cross-sectional research design is a research approach in which the researchers investigate the state of affairs in a population at a certain point in time. Very often, the elements in the sample survey are selected at random to make inference about the population as a whole [21]. 


\subsection{Target Population}

The target population of this study comprised of the commercial banks in Nakuru County while the respondents were the operations managers and IT technicians of the commercial banks in Nakuru County. There are 56 operations managers and IT technicians in all the commercial banks branches. Since the banks were few, the study adopted a census survey.

\subsection{Data Collection}

Primary data was collected regarding the relationship between Internet banking and operational performance. Data was collected using structured questionnaires. The questionnaires were administered to the respondents through drop and pick method.

\subsection{Data Analysis and Presentation}

Data was collected, coded and analyzed through SPSS version 21. Pearson Product-Moment correlation was used to test the relationship internet banking and operational performances. ANOVA test was used to determine the level of significance of the relationship between internet banking and Operational Performance. Hypothesis was tested at 5\% significance level. The following general multiple regression model below was used in the study.

$$
Y=\beta_{0}+\beta_{1} x_{1}+\varepsilon
$$

Where:

$\mathrm{Y}=$ Operational performance

$\beta_{0=}$ Constant

$\beta_{1}=$ Regression Coefficients

$\mathrm{X}_{1}=$ Internet Banking

$\varepsilon=$ Error Term

\section{Findings and Recommendations}

\subsection{Correlation Analysis Between Internet Banking and Operational Performance}

A correlation analysis was conducted to establish the relationship between Internet banking and operational performance. The results of the analysis were as presented in Table 1.

Table 1. Correlation analysis between Internet Banking and Operational Performance.

\begin{tabular}{|c|c|c|c|}
\hline Variables & & Internet Banking & Operational Performance \\
\hline \multirow{4}{*}{ Internet Banking Operational Performance } & Pearson Correlation & 1 & 0.000 \\
\hline & Sig. (2-tailed) & & \\
\hline & & $.597^{* *}$ & 1 \\
\hline & $\mathrm{N}$ & 26 & 26 \\
\hline
\end{tabular}

Source: Research Data (2016).

\subsection{Hypothesis Testing}

$\mathrm{H}_{01}$ : Relationship between Internet Banking and Operational Performance.

The study sought to investigate the effect of Internet banking on operational performance of commercial banks. It was hypothesized that Internet banking has no significant effect on operational performance. The results in Table 1 showed that there was a significant positive correlation between internet banking and operational performance $(\mathrm{r}$ $=597, \mathrm{p}<0.05)$. According to the results the hypothesis that Internet banking has no significant effect on operational performance of commercial banks was rejected. It was therefore, concluded that Internet banking affects operational performance. The findings of this study are in line with the findings of [8] who concluded that Internet banking positively and significantly influences the operational efficiency of commercial banks in Kenya. The findings are also consistent with the findings of [10] who concluded that banks that provide extensive online banking services tend to perform better than those who lag behind and that online banking improves the earnings of the banks.

\subsection{Regression Analysis Between Internet Banking and Operational Performance}

A regression analysis was conducted to establish the extent of the relationship between internet banking and operational performance. The results were as shown in Table 2.

Table 2. Regression Analysis for Internet Banking and Operational Performance.

\begin{tabular}{lllll}
\hline Model & R & R Square & Adjusted R Square & $\begin{array}{l}\text { Std. Error of } \\
\text { the Estimate }\end{array}$ \\
\hline 1 & $.656^{\mathrm{a}}$ & .430 & .422 & .48841 \\
\hline
\end{tabular}

Source: Research Data (2016).

Predictors: (Constant), Internet Banking

The model summary of the regression analysis in Table 2 showed that internet banking accounted for $43 \%$ of the variance in operational performance in the commercial banks branches in Nakuru County $(\mathrm{R}$ Square $=0.430)$. This explains that $57 \%$ of the variance in operational performance was explained by variables not in the study.

Table 3. Significance of the Relationship between Internet Banking and Operational Performance.

\begin{tabular}{llllll}
\hline ANOVA $^{\mathbf{a}}$ & & & & & \\
\hline Model & Sum of Squares & Df & Mean Square & F & Sig. \\
\hline Regression & 38.018 & 3 & 12.673 & 53.126 & $.000^{\mathrm{b}}$ \\
Residual & 50.332 & 23 & .239 & & \\
Total & 88.351 & 26 & & & \\
\hline
\end{tabular}

a. Dependent Variable: Operational Performance

Predictor: (Constant), Internet Banking 
From Table 3, the significance value (p) of 0.000 gives the test on the entire model. Since the value of $p<0.05$, this implies that Internet banking has statistical significant relationship with operational performance.

Table 4. Table of Coefficient.

\begin{tabular}{cllll}
\hline \multirow{2}{*}{ Model } & \multicolumn{2}{l}{ Unstandardized Coefficients } & \multicolumn{2}{c}{ Standardized Coefficients } \\
\cline { 2 - 3 } Sig. & Std. Error & Beta & 9.855 \\
\hline (Constant) & 1.761 & .179 & & .000 \\
Internet Banking & .204 & .078 & .260 & .000 \\
\hline
\end{tabular}

Source: Research Data (2016)

a. Predictor: Internet Banking

b. Dependent Variable: Operational Performance

Table 4 shows the significance (p) values for the independent variable internet banking. If $p<0.05$, the conclusion is that the independent variable is a predictor of the dependent variable. In testing the relationship between internet banking and operational performance, significance value (p) of 0.000 which is less than 0.05 shows that internet banking has statistical significant relationship with operational performance. The unstandardized coefficient shows that for every unit increase in Internet banking, a 0.204 unit increase in operational performance is predicted. Therefore, the equation for the regression model was given by:

$$
Y=1.761+0.260 x_{1}
$$

Where:

$$
\begin{aligned}
& Y=\text { Operational Performance } \\
& \beta_{0=\text { constant }} \\
& \beta_{1}=\text { Regression Coefficient } \\
& X_{1}=\text { Internet Banking }
\end{aligned}
$$

\subsection{Conclusions}

The objective of the study was to investigate the effect of internet banking on operational performance of commercial banks in Nakuru County. The study concluded that internet banking is highly related with operational performance. This shows that the adoption of internet banking has a positive influence on operational performance. This correlates the study by [15] who found that the adoption of internet banking has enhanced performance of the banking industry due to increased efficiency, effectiveness and productivity.

\subsection{Recommendations}

The aim of this study was to investigate the effect of internet banking on operational performance of commercial banks in Nakuru County, Kenya. The findings of this study have various implications for management of commercial banks and management policy and practice. The study revealed that there is a link between Internet banking and operational performance; hence, Internet banking affects operational performance. This implies that internet banking is essential for an increased operational performance. Thus, to create a competitive edge and improve operational performance, commercial banks need to invest more in Internet banking.

\subsection{Suggestions for Further Study}

More academic research should be conducted to establish the effect of Internet banking on operational performance in other sectors other than banking as the study focused only on commercial banks in order to establish whether internet banking does affect their operational performance.

\section{References}

[1] Abdullahi, Y. (2012). Services Automation and Performance: Evidence from Deposit Banks in Nigeria. International Journal of Advanced Research in Management and Social Sciences, 1 (2), 47-58.

[2] Aduda, J., \& Kingoo, N. (2012). The Relationship between Electronic Banking and Financial Performance among Commercial Banks in Kenya. Journal of Finance and Investment Analysis, 1 (3), 99-118.

[3] Agboola, A. A. (2003). Information Technology, Bank Automation and Attitude of Workers in Nigerian Banks. Journal of Social Science, 7 (3), 215-222.

[4] Chibueze, Z., Maxwell, O., \& Osondu, M. (2013). Electronic Banking and Bank Performance In Nigeria. Abia State University, Imo State University.

[5] Davis, F. D., Bagozzi, R. P., \& Warshaw, P. R. (1989). User Acceptance of Computer Technology: A Comparison of Two Theoretical Models. Management Science, 35 (8), 982-1003.

[6] Foley, P., \& Jayawardhena, C. (2000). Changes in the Banking Sector- The Case of Internet Banking in the UK Chanaka Jayawardhena and. Internet Research, 10 (1), 19-31.

[7] Gizaw, B. (2016). The Effect of Suuply Chain Integration on Operational Performance in Ethiopian Trading Enterprises. Addis Ababa University.

[8] Guyo Jattani. (2014). Effect of Technology Adoption on Operational Efficiency of Commercial Banks in Kenya. University of Nairobi.

[9] Jenkins, H. (2007). Adopting Internet Banking Services in a Small Island State: Assurance of Bank Service Quality. Managing Service Quality: An International Journal, 17 (5), 523-537. http://doi.org/10.1108/09604520710817343.

[10] Kagan, A., Acharya, R. N., \& Rao, L. S. (2005). Does Internet Banking Affect the Performance of Community Banks (No. 85212). Arizona. 
[11] Kumar, V., Batista, L., \& Maull, R. (2011). The Impact of Operations Performance on Customer Loyalty. Service Science, 3 (2), 158-171.

[12] Muthami, J. (2015). Effect of Logistics Outsourcing on the Operational Performance of Shipping Industry in Kenya. University of Nairobi.

[13] Njogu, N. J. (2014). The Effect of Electronic Banking on Profitability of Commercial Banks in Kenya. University of Nairobi.

[14] Ngugi, K., \& Karina, B. (2013). Effect of Innovation Strategy on Performance of Commercial Banks in Kenya. International Journal of Economics and Finance, 1 (3), 1-13.

[15] Okiro, K., \& Ndungu, J. (2013). The Impact of Mobile and Internet Banking on Performance of Financial Institutions in Kenya. European Scientific Journal, 9 (13), 146-161.

[16] Pikkarainen, K., Pikkarainen, T., Karjaluoto, H., \& Pahnila, S. (2004). Consumer Acceptance of Online Banking: An Extension of the Technology Acceptance Model. Internet Research, 14 (3), 224-235. http://doi.org/10.1108/10662240410542652.
[17] Rahman, S., Laosirihongthong, T., \& Sohal, A. S. (2010). Impact of Lean Strategy on Operational Performance: A Study of Thai Manufacturing Companies. Journal of Manufacturing Technology Management, 21 (7), 839-852. http://doi.org/10.1108/17410381011077946.

[18] Samuel, O., Matrix, D., \& Solutions, B. (2011). ICT's, Service Delivery and Operational Performance in Nigerian Banks : A Survey of Empirical Research. African Research Review, 5 (21), 44-59.

[19] Vutsengwa, R. M., \& Ngugi, K. (2013). An Assessment of The Challenges Facing Commercial Banks in Kenya: A Case of Commercial Banks. International Journal of Economics and Finance, 1 (2), 1-8.

[20] Wario, A. Y., \& Okibo, B. W. (2014). Effects of E-Banking on Growth of Customer Base in Kenyan Banks. International Journal of Research in Management \& Business Studies, 1 (1), 78-84.

[21] Zheng, M. (2015). Conceptualization of Cross-Sectional Mixed Methods Studies in Health Science: A Methodological Review. International Journal of Quantitative and Qualitative Research Methods, 3 (2), 66-87. 